UDC 614.84

DOI https://doi.org/10.32846/2306-9716-2019-2-25-1

\title{
FIRE ENGINEERING PULSE MODELING VORTEXES AND SQUALLS TO ENSURE ENVIRONMENTAL SAFETY IN EMERGENCY SITUATIONS
}

\author{
Bondar A. ${ }^{1}$, Zahmatov V. ${ }^{1}$, Sherback N. ${ }^{2}$ \\ ${ }^{1}$ State Ecological Academy of Postgraduate Education and Management \\ Metropolitan Vasyl Lipkivsky str., 35, bldg. 2, 03035, Kyiv \\ dei2005@ukr.net, zet.pulse@gmail.com \\ 2 "GuiproGrahdanStroy" \\ Gogolivska str., 22-24, 01054, Kyiv \\ vksys.nikolay@gmail.com
}

\begin{abstract}
Public disorders in Ukraine (2013-2014), France, Venezuela, Greece, the USA are accompanied by numerous arsons of homes, dozens of cars, emissions of toxic substances, the use of toxic incendiary compounds. This led to great material damage, numerous poisonings, and the creation of long-lived toxic zones. One of the main reasons is the absence of fire and rescue equipment capable of safely, effectively and on a large scale extinguishing burning people and burning houses, shops, vehicles with incendiary bottles, quickly precipitating carcinogenic smoke from burning tires and extinguishing them. Describes a fast and effective way of possible counteraction to fire, toxic and environmental threats, by modeling natural phenomena - water squalls, sandy - dust vortices, safe for people - tested at landfills. Implemented flexibly controlled formation of squalls, eddies in specified areas and in buildings. Models of squalls, vortices exist for a specified time and with the required intensity, accurately dosed, controlled over the entire area of impact. It is proposed to interested organizations and firms to consider the issue of appropriate revision of a new type of fire equipment and testing to determine the possibility of using it as a new type of multi-protection technology. Key words: mass disorder, incendiary bottles, arson, fire extinguishers, multilateral modules on the chassis, tank, armored personnel carrier, jeep, fire extinguishing compositions, powder, liquid, gel; natural soil, sand, mud, water.
\end{abstract}

Пожежна техніка імпульсного моделювання вихорів і шквалів для забезпечення екологічної безпеки під час надзвичайних ситуацій. Бондар О.І., Захматов В.Д., Щербак М.В. Масові протести в Україні (2013-2014), Франції, Венесуелі, Греції, США супроводжуються численними підпалами будинків, десятків машин, викидами токсичних речовин, застосуванням токсичних запальних складів. Це призвело до великого матеріального збитку, численних отруєнь, створіння довготриваючих токсичних зон. Одна з головних причин - відсутність пожежно-рятувальної техніки, здатної безпечно, ефективно $\mathrm{i}$ масштабно гасити палаючих людей і підпали магазинів, автотранспорту, будинків, що зроблені запальними пляшками, швидко осадити канцерогенний дим від палаючих покришок і згасити їх. Описується швидкий та ефективний шлях можливої протидії пожежним, токсичним і екологічним загрозам за допомогою моделювання природних явищ - водяних шквалів, піщано-пилових вихорів, безпечних для людей, що перевірено на полігонах. Реалізується гнучко кероване формування шквалів, вихорів на заданих територіях і в будівлях. Моделі шквалів, вихорів існують протягом заданого часу, з необхідною інтенсивністю точно дозуються, $\epsilon$ контрольованими на всій площі впливу. Зацікавленим організаціям і фірмам пропонується розглянути питання відповідного доопрацювання нового виду пожежної техніки та проведення випробувань для визначення можливості використання іï як нового виду техніки багатопланового захисту. Ключові слова: масовий безлад, запальні пляшки, підпали, вогнегасники, багатостовбурні модулі на шасі, танк, бронетранспортер, джип, вогнегасні суміши: порошок, рідина, гель; природні: грунт, пісок, бруд, вода.

Пожарная техника импульсного моделирования вихрей и шквалов для обеспечения экологической безопасности при чрезвычайных ситуациях. Бондарь А.И., Захматов В.Д., Щербак Н.В. Массовые протесты в Украине (2013-2014), Франции, Венесуэле, Греции, США сопровождаются многочисленными поджогами домов, десятков машин, выбросами токсичных веществ, применением токсичных зажигательных составов. Это привело к большому материальному ущербу, многочисленным отравлениям, созданию долгоживущих токсичных зон. Одна из главных причин этого - отсутствие пожарно-спасательной техники, способной безопасно, эффективно и масштабно тушить горящих людей и поджоги домов, магазинов, автотранспорта, сделанные бутылками с зажигательными смесями, быстро осадить канцерогенный дым от горящих покрышек и потушить их. Описывается быстрый и эффективный путь возможного противодействия пожарным, токсичным и экологическим угрозам путём моделирования природных явлений - водяных шквалов, песчано-пылевых вихрей, безопасных для людей, что проверено на полигонах. Реализуется гибко управляемое формирование шквалов, вихрей на заданных территориях 
и в зданиях. Модели шквалов, вихрей существуют в течение заданного времени с требуемой интенсивностью, точно дозируемой и контролируемой на всей площади воздействия. Заинтересованным организациям и фирмам предлагается рассмотреть вопрос соответствующей доработки нового вида пожарной техники и проведения испытаний для определения возможности использования её как нового вида техники многоплановой защиты. Ключевые слова: массовый беспорядок, бутылки с зажигательной смесью, поджоги, огнетушители, многоствольные модули на шасси, танк, бронетранспортёр, джип, огнетушащие составы: порошок, жидкость, гель; природные: грунт, песок, грязь, вода.

The real clashes of the opposing sides in the zones of mass riots, operations to neutralize terrorist groups, military conflicts - are inevitably accompanied by largescale, environmentally dangerous, toxic consequences: burns for tens of seconds 2, especially 3 degrees, the constant wild pain from which even strong painkillers do not drown out, store burns Houses;

2 - in zones of mass unrest control over emergency hazardous objects is lost -2.1 . burning houses, without timely access of firefighters, in which sudden emissions of household gases from gas pipelines destroyed by the flames with the formation of burning gas jets and inevitably exploding are possible, which greatly increases the destruction in burning houses and underground highways; toxic gases from industrial refrigerators, pools; power outages leading to accidents, etc. $[1 ; 2 ; 3]$.

Examples of exporting "color revolutions" show the urgent need for a new generation of fire extinguishing equipment, prevention of volumetric explosions, localization of radioactive emissions, deposition and neutralization of toxic gases, NSO vapors. It is desirable that this technique was universal and not difficult to assemble and manage a squad of various fire and rescue vehicles with numerous managers and service personnel working in deadly conditions. A new technique must be well protected, at least from small arms, and quickly, effectively, without long preparation, localize and stop fires and other above-mentioned emergencies in the context of aggressively opposing sides, active radical groups, many residents and passive demonstrators, observers, onlookers. We can formulate the basic requirements for a new technique: 1 - effective, large-scale, immediate halt of the active development of emergency situations in a given area of a dangerous zone of confrontation, 2 - spraying of non-toxic fire extinguishing and protective compounds that simulate, in the required ranges of scale and power, natural squalls, whirlwinds; 3 - largescale spraying of standard, non-toxic compositions and natural inert materials is carried out only within seconds by pulsed powerful, long-range vortices with a rapidly expanding front, ensuring the magnitude of the impact and, as a consequence, the speed of quenching and protection operations $[2 ; 3 ; 6]$.

The first type of control of riots and liquidation of their consequences was fire equipment, water jets, cooling political passions and the aggressiveness of the crowd, using mostly cobblestones. Currently, dozens of samples of special water cannons on armored chassis have been developed to control riots. However, firefighters with their equipment in the US, Europe are actively involved in the control of riots primarily to eliminate arson. For example, in the United States, the construction of the "pig" type is used to clean the street from the crowd of insurgents, the first row in the center of 1-2 of the National Guard under armored personnel carrier with heavy machine guns, armored vehicles with water cannons to the right and left, and cars and buses with police and national guard in the second row, in the third row, fire trucks to extinguish arsons and fires on the route of the detachment, as well as to quickly extinguish burning police officers from incendiary bottles $[10 ; 11]$.

Traditional fire equipment is unsuitable for eliminating the effects of attacks and outrages of radicals - extinguishing burning policemen, burning houses, shops, leaks and emissions of toxic substances, including the deposition of toxic and thick clouds of smoke, before they cover crowds of people who do not have time to escape due to crowding on the limited space of squares and streets.

Pulsed spraying volleys Multiple Modules (IMU) many times exceed in range, scale, flow rate and, as a result of speed and uniformity of impact, the most powerful traditional aerodrome fire engines. A high degree of superiority in these parameters results in a new quality of extinguishing and protection. For example, the most important circumstance in extinguishing and protecting in human settlements is the effective use of nontoxic fire extinguishing agents, natural water, sand, dust; extinguishing arsons, including terrorist ones, using combat, incendiary compositions and fires of all classes, including developed ones; production of instantaneous heat and light protective curtains, prevention of volumetric explosions, localization of oil and oil products bottling, sedimentation and neutralization of large, toxic clouds and smoke. A salvo spray will provide flexible control of the scale, configuration, speed, and width of the front of pulsed Vortices and Squalls [11].

Very important is the possibility of effective spraying of gels and sand, which are practically not sprayed by pneumatic and hydraulic equipment. These compounds have no alternative for extinguishing chemical materials that are not compatible with water, burning wood, metals, etc. The compositions destroy the surface burning zone and effectively cool its fragments. About $90 \%$ of a viscous composition is used to cool the extinguished combustible surface, while water is used effectively by no more than $30 \%$ due to the rebound of water droplets larger than 100 microns from the surface of the heated material and from the burning zone, draining water films from the cooled surfaces. Sprayed viscous, gel-like paints are very relevant for controlling riots, but there is no technology for large-scale spray paints over a large 
area. This could solve the problem of search and arrest of radicals outside the demonstration zone. Massive coloring of radicals and demonstrators, especially quickly in large areas, will almost guarantee the decline of militant mood and the voluntary withdrawal of the overwhelming majority of demonstrators, or at least suppress radical actions, turning an aggressive demonstration into a peaceful one.

Changing the number and relative position of the shafts flexibly adjusts the dynamic parameters of the Squall (Vortex) front parameters - area, shape, depth, concentration of the sprayed agent, speed, angle of the front meeting with the hot, charred zone. As a result, flexible control of the power and type of functional effect by extinguishing, protective, localizing, irritating effects is achieved, along with changing the type of sprayed agent.

When protecting critical objects from fire, explosion, toxic clouds or sabotage radicals, terrorists and saboteurs - machines with MM should come to the position or stand constantly on it, as elements of an automatic system charged and ready for immediate action without any additional preparation. This will allow the most quickly extinguish the ignition, fire, prevent an explosion, localize the blast wave, stop the terrorists on the perimeter of the object with a series of powerful squalls, whirlwinds. Only MM can be effective for extinguishing multiple arson in a large area, a wide street from the mass throwing of plastic, incendiary bottles by hand, cans, from catapults and pneumatic mortars. MM can quickly and repeatedly create a series of squalls of a soft shock, gas-and-drop wave, outwardly similar to a tsunami, of a frightening appearance and rapidly spreading. There is a choice or people will burn, getting serious burns disfiguring them - or they will be immediately saved from burns, but at the same time they will be hurt to a certain degree, but not injured by their savior - a squall. From one type of Squall, even from a safe distance, most of the demonstrators will run back. A wave of squall will also put out all the burns. At the same time, there is an obvious need to find a compromise between two opposite positions: 1-A fire extinguisher squall should immediately cover a large area with the effect of continuous extinguishing, therefore it must be high-speed, largesized, powerful, possessing large kinetic energy, a shock effect and creating an internal multi-vortex structure torque dumping people; 2 - the above-mentioned types of human impact on large-scale quenching or protection should be minimized, in particular, first of all: impact and vortex torque.

A special case - people in burning clothes - undoubtedly the most important thing is the speed of extinguishing - bringing down the Flame. It is better to endure the direct impact of a powerful Squall (Whirlwind) even at close range in people without causing severe injuries or injuries than to delay at least a few seconds to knock the flames down and thereby expose evacuees to serious burns. Fast extinguishing can be performed by a local flurry of a manual anti-extinguisher for one person or a compact group of 2-3 people or a large Squall, providing a fairly powerful extinguishing effect in an area of up to 1000 sq. M which may contain several people. For a standard salvo, for example, from 10 trunks, if there is time, a position should be selected from which the impact of the flow cannot lead to concussions with concussions of the brain.

So far, no computational methods and mathematical models have been created that correctly reflect the most complex, multiphase process of the formation and propagation of a pulsed, gas-dispersed flow. This is due to the insufficient degree of study of this non-stationary complex process, interfacial interaction, in particular, the absence of heat exchange, mass transfer, acceleration coefficients. Without these coefficients, it is impossible to make a calculation of the propagation distance of a pulsed gas-dispersed flow, at least close to real conditions, in particular for our task to calculate the parameters of the flow front, velocity, density, area, depth to estimate the dynamic effect of the flow on a person. If it is impossible to carry out a correct calculation even for a simplified case of movement of a segment of a laminar, pulsed gas-dispersed jet, with variable density and pressure along the length of this segment, then it is all the more impossible to calculate the current parameters of a pulsed, vortex, gas-dispersed flow. Only the experimental path remains scientifically correct.

In order to study the nature of the gas-droplet squall (gas-dust vortex) on people, experiments were conducted at the sites. The spraying was carried out from the fire, armored, tracked Impulse- 3 vehicle - the chassis of the T-62 tank with a 50-barreled turret module, barrels with a caliber of $200 \mathrm{~mm}$, length of $1600 \mathrm{~mm}$ (8 calibers). $25 \mathrm{~kg}$ of powder or 10-15 liters of water are loaded into the barrel bore. In total, in the Pug trunks = $1.225 \mathrm{~kg}$ or $500-750$ liters of water. The module is universal, effectively sprays powders, liquids, water, foam solutions, gelatins, sand, soil, dust, snow. In the experiments were used:

- fire extinguishing powder of the "Pirant-M" brand with dispersion from 20 to 70 microns, density of $1.2 \mathrm{~g} / \mathrm{cm}^{3}$;

- fire extinguishing powder with inclusions of fine crushed stone with dispersity from 3 to 5 micron, density of $1.8 \mathrm{~g} / \mathrm{cm}^{3}$; the purpose of the introduction of fine crushed stone into powder is to simulate the inclusions of crushed powder, which do not collapse when exposed to a blast wave, fly a considerable distance, like stones, and can injure evacuees; - river sand of dispersion of $0.1 \mathrm{~mm}$, density of $1.4 \mathrm{~g} / \mathrm{cm}^{3}$; - tap water.

The Vortex front extended to 120-140 m (Fig. 1c), the front lost a critical density on a segment of the trajectory further $90 \mathrm{~m}$, the jets of oncoming air penetrated into the front. which led to its explosive expansion and, accordingly, inhibition with intense destruction. As a result, the Whirlwind transformed into a cloud, dissipated under the influence of the wind over a period of 3 to $10 \mathrm{~min}$ (Fig. 1d), depending on the strength of the 
wind. When moving along the trajectory, the vortex had a drop-like shape with a pronounced frontal thickening $\mathrm{PV}$, close in shape to a hemisphere, convex toward the direction of propagation. The PV slid along the road surface - close to the surface - the stream, as if coming off from the cuts of the trunks, pressed against the ground and then flattened out along it (Fig. 1c). The width of the EF increased more than the height, which varies little with respect to the ground from $3 \mathrm{~m}$ (the height level of the upper row of MM trunks) to 4-5 m. But in the horizontal plane, when spraying in open space without obstacles, the EF cross section expands to 15-17 m, like a drop of water on a smooth, specular surface or a storm wave.

Behavior of people under the impact of the front of the Whirlwind (Squall) in the zone of the flow is the same - to fall to the ground, curl up into a lump, closing his eyes, mouth, nose - with his hands and clothes. The behavior of people while they are practically not controlled by them because of the powerful short-term, complex effects of PV, combining a number of damaging and irritating factors:

- shock effects of HF, dumping people without causing them wounds or injuries;

- the blows of conglomerates of compressed powder or cardboard fragments of a container that collapsed in the trunk, these blows caused bruises of varying severity, injured exposed skin;

- vortex, twisting effect of the stream, dumping people;

- instant creation of an opaque, optically dense gas-dispersed medium consisting of suspended particles of fine fire extinguishing powder, chemically active when interacting with water - wet surfaces and therefore irritating to the respiratory system, smell, sight. Highspeed, penetrating the deposition of powder particles on the wet surface of the eyeballs, oral cavities, nose greatly enhances the irritant effect.

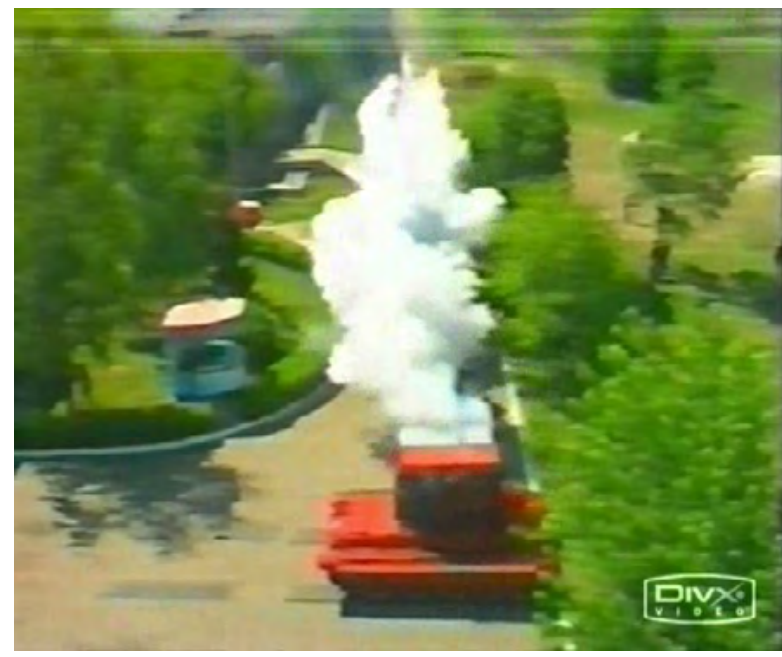

1
The participation of physicians in the tests allowed to establish that the behavior of people caught in the zone of impact of the Whirlwind is characterized by the following features:

- loss of balance up to the fall due to the effect of surprise in combination with a powerful but relatively soft, not damaging blow of PV, comparable to the blow of a squall at sea, a storm wind or a storm wave with a wave of 2-3 points at the time of roll-up on the sloping shore, beach;

- instant loss of visibility, orientation due to the fact that a person suddenly finds himself in an opaque - optically dense medium, simultaneously losing balance and orientation due to the strong shock of the HF;

- strong irritating effect on the organs of vision and respiration - burning in the eyes, mouth, nasal cavity, ears tightly clogged with powder and dust - as a result, vision does not work, breathing is difficult, smell.

- a person in the impact zone involuntarily, falls or falls to the ground, compressed into a lump, covering the organs of sight, breath, smell by the sleeves.

The front of the stream spreads quickly, so the above-mentioned forms of influence occur completely unexpectedly, even for trained people who are waiting for this impact and have been warned in advance about it. The sensations of the author standing in the center of the first row of participants in a group of volunteers are the first sound from a spray shot, close in volume to the sound of a gun shot with a caliber of 37 or $45 \mathrm{~mm}$. Immediately after the shot, a powerful whirlwind hits the test subject - dumping, twisting, knocking down. At the same time, the visibility disappears, and the eyes, ears, nose, and mouth become clogged with fine powder, dust, and powder smoke, irritating the mucous membranes.

An ordinary demonstrator and even a specially trained radical have a strong, complex effect: - loss of orientation, balance, self-control and the ability to actively act. Before the experiment, volunteers put on

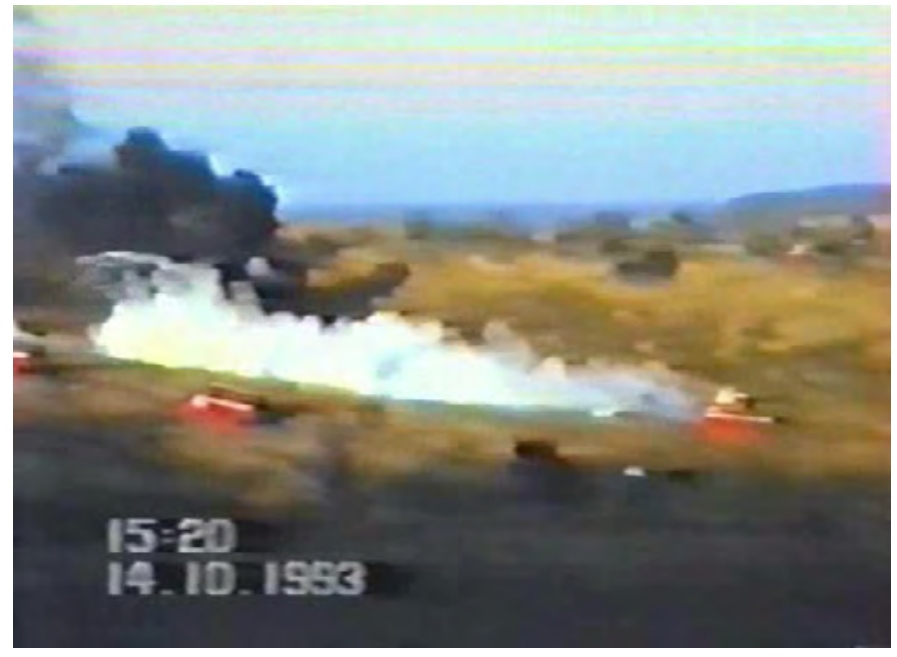

2

Fig. 1. Quenching local class B foci at a distance of up to $110 \mathrm{~m}$ by salvo spraying $200 \mathrm{~kg}$ of powder from 10 barrels, extinguishing a class $B$ hearth of $200 \mathrm{~m}^{2}$ from a distance of $60 \mathrm{~m}$ (Cherkasy) 
tight goggles, respirators, and overalls with hoods, reliably protecting them from irritating effects. At the same time remained: invisibility, shock from the blow, loss of balance, orientation, lack of control of behavior and activity. After passing through the Whirlwind front, the volunteers found themselves inside a dense, opaque cloud. Therefore, at the second stage, it is advisable to use Squall - a gas-droplet impulse ejection, effectively a squall front (FSH), precipitating a powder cloud and cooling burning surface, for example, police and civilian clothes, possible sources of re-ignition - charred surfaces of leather, thick clothing that effectively prevent ignition and reduce the degree of burn people.

If it is not possible to fall to the ground, the road, the floor of the room, then you must turn your back on the SHF, as if protected from a dusty whirlwind, a gust of wind saturated with dust. It is advisable to create the first Whirlwind with a volley from MM from a distance of more than $60 \mathrm{~m}$ from the crowd of demonstrators in order to reduce the impact force of the Whirlwind front (see Figure 1a). In this case, it is advisable to place the MM around the fire in positions so that the shock Front would have less impact directly on the people being evacuated and the vortex trajectory would pass along the tangent and evacuation routes.

After cutting off evacuees from the flame, one pulsed machine with a MM should continue to guard the evacuation routes, and the rest should extinguish the burning area. Evacuees and rescuers must quickly get up and run through the passage formed by the FSH in the wall of the flame, until re-ignition occurs, restoring the wall of fire. This is prevented by shock from the impact of the Front, severe irritation of powder particles on the eyes, mouth, nose, lack of visibility. To eliminate these effects, the MM-machine from a distance of more than $30 \mathrm{~m}$ gives a volley of water, creating a squall of water mist precipitating a gas-powder cloud. A squall compared to a gas-powder Swirl has a less dense front, there are no compressed powder conglomerates, which can traumatize its impact, the dynamic effect is much softer, weaker, there is a push effect comparable to a brief shower-squall. Squall front for 2-3 seconds will precipitate the powder cloud and eliminate the irritating effect on the organs of sight, respiration and smell, and fine droplets will eliminate the shock. This will allow people to quickly recover and retire to a safe distance from the Flame and the heat radiation of arson, fire and an explosively burning object, such as an emergency plane, spilled aviation fuel.

A combination of bursts of powder and then finely dispersed water is most effective for extinguishing arsons, fires on streets, squares, so that powder clouds do not frighten people. The optimal tactics for using $\mathrm{MM}$ is first to launch a volley of powder from a long, safe distance for the MM machine, a distance with the aim of a Vortex, an effective, quick churning of the flame, and then a squall of mist water for intensive volumetric cooling and preventing re-ignition. This is the most acceptable complex effect, combining sequential whirlwind protects from flame, thermal radiation, and Squall brings psychophysiological parameters to normal in people affected by the Whirlwind, while creating an evacuation passage for them from the Fire Zone.

In terms of long-term effects, the option of using environmentally friendly substances that actively affect human organs, only in a dynamic or suspended state, for example, in the form of a high-speed gas-dispersed flow or cloud, is the least dangerous. It can be common, widespread natural materials: clean water, sand, soil, dirt, fine crushed stone, dust - natural or cement. The requirements for recovery ability - flexible adjustment of the intensity, duration, and scale of exposure - are imposed on promising designs of a wide range of technology for extinguishing and protecting:

- the implementation of multiple salvo exposure with intervals that determine the effect of maintaining the necessary scale and intensity - the power of artificial vortices;

- adjustment - the choice of a number of standard schemes for changing the number and relative position of the barrels in the salvo, which allows you to precisely adjust the range, area and intensity of the effective vortex effect;

- the use of, in addition to multilateral installations, outboard helicopter containers, containers for Dronov, allows them for the first time to be used for effective extinguishing and protection, as well as long-range hand-held sprayers;

- instant precipitation, in whole or in part, of an optically dense gas-powder cloud using a vortex of sprayed water;

- effective, large-scale spraying of viscous and sticky compounds, for which conventional hydraulic equipment is unsuitable, due to failures in operation. Suspended helicopter containers spray 50, 100, 150 or $200 \mathrm{~kg}$ of liquid, gelatin, powder or sand from a height of $10-30 \mathrm{~m}$ above the target and create an intense Squall (Whirlwind) up to $5 \mathrm{~m}$ in height in the surface layer of the atmosphere. When destroyed, the light container body does not form damaging fragments, the wave energy of the explosion products preferentially passes into the mass of the sprayed agent, there fore the shock effect from the explosive spraying at a distance of more than $80 \mathrm{~m}$ from the blasting epicenter is characterized only by an acoustic sound without a striking effect.

Spray from the container is safe for direct exposure to people and is most effective for salvo, square-nesting extinguishing fires, arson, localization of carcinogenic smoke from burning tires, toxic emissions, bottling and decontamination according to a given program, section by section, respectively, commands from the ground .

Container is effective for spraying gelatin with the effect of penetrating detonation spraying of its droplets on the surface, due to kinetic energy and multiple reflections, continuous application of the composition to a complex surface is realized. This will ensure fast pro- 
cessing of large areas and improve the quality of impact by increasing the speed and scale of the impact.

To stop the attacks of radicals, terrorists on important objects: nuclear and thermal power plants, gas and oil, chemical, military objects, such as ammunition bases, a very effective method of using bombs is to use them as stationary spray devices located along the perimeter, protected area or hangars. To create a surprise effect, these devices can be disguised as luminaires located on the perimeter, territory or inside the object (Fig. 2). Photo 3 shows two episodes of testing Stationary, suspended spraying devices located on the perimeter of the protected object and disguised as luminaires present on the poles of this perimeter: $\mathrm{a}-$ sputtering stage $0.15 \mathrm{~s}$ after initiation, $\mathrm{b}$ - formed optically dense cloud on an area up to $350 \mathrm{~m}^{2}$ after $1.5 \mathrm{~s}$ after initiation, covering the group of terrorists with an optically dense, highly irritating medium.

Another effective tool is a manual "bazooka", at least outwardly similar to it. This is a whole range of single-barrel, three-and four-barrel pulse dispensers in one shot $0.35 ; 0.5 ; 0 ; 1.5$ and $2 \mathrm{~kg}$ of powder, liquid, water, sticky substance or soil, sand, dirt, dust, gravel. For military units, they are well acceptable, especially a mini-device - mini-extinguisher - for personal protection, right up to hand-to-hand combat and a single-barreled "bazooka-grenade launcher", spraying various compositions up to a distance of $30 \mathrm{~m}$. Kalashnikov, above all on reliability, unpretentiousness in all weather conditions, including frost, mud, rain, snowfall, blizzard, dust storm, sandstorm, cheapness of mass production, simplicity of production, operation and maintenance, as well as the power of action and versatility, naturally taking into account the various tasks to be solved. A bazooka can spray special formulations, such as irritating irritants in light containers, localizing people with a viscous film of rapidly polymerizing compositions, air-extinguishing agents, and the main inexhaustible source of natural materials that work effectively with finely dispersed. This bazooka can be used for autonomous, multiple extinguishing, for the first time regardless of the supply of fire extinguishing compositions, which gives a new

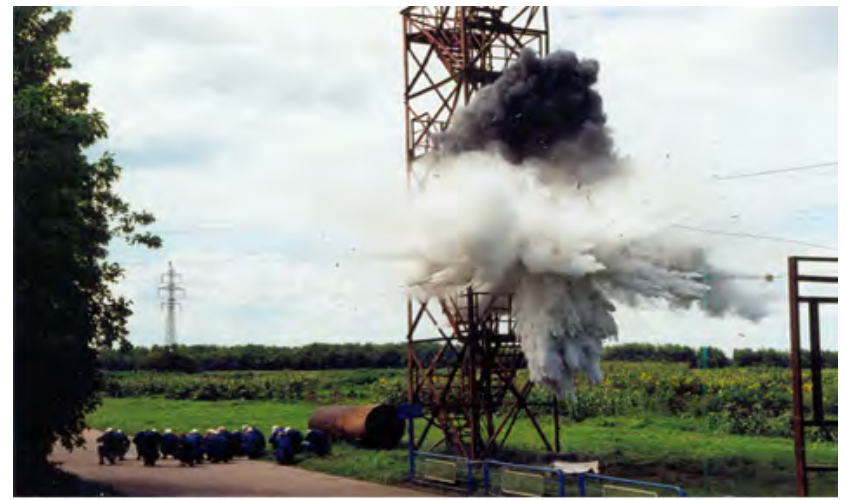

Подвесная бомба для крана, вертолета. Площадь воздействия до 300 кв. м., еффективна для освобождения заложников и локализации террористов, на улицах, площадях, в отдельном доме, квартале, в лесу, на поляне, для остановки автомобиля, автобуса, грузовика на дороге.

Suspend bomb for crane, helicopter. Influence square up to 300 sq. m. It's effective for localization of terrorist, freedom of hostages at single building, stop the pasage at street, from square, stop the group, car, bas, lorry on the roaud.

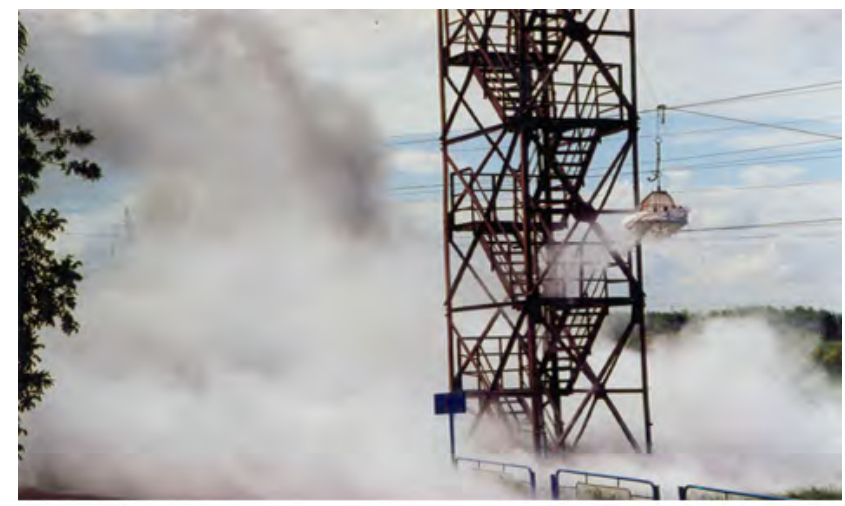

Длительность вихревого воздействия до 5 сек, непрозрачного слабораздражающего облака до 3 мин. Период полной самостоятельной реабилитации не менее 20 мин, нет последствий для здоровья.

Period of single, combine, powerful, influence up to $5 \mathrm{sec}$, nonvisible poor irritanting cloud up to $3 \mathrm{~min}$. Completely selfservice reabilitation period up to $20 \mathrm{~min}$. No consequences for health.

$a$

$b$

Fig. 2. Stationary, suspended spray devices located on the perimeter of the protected object
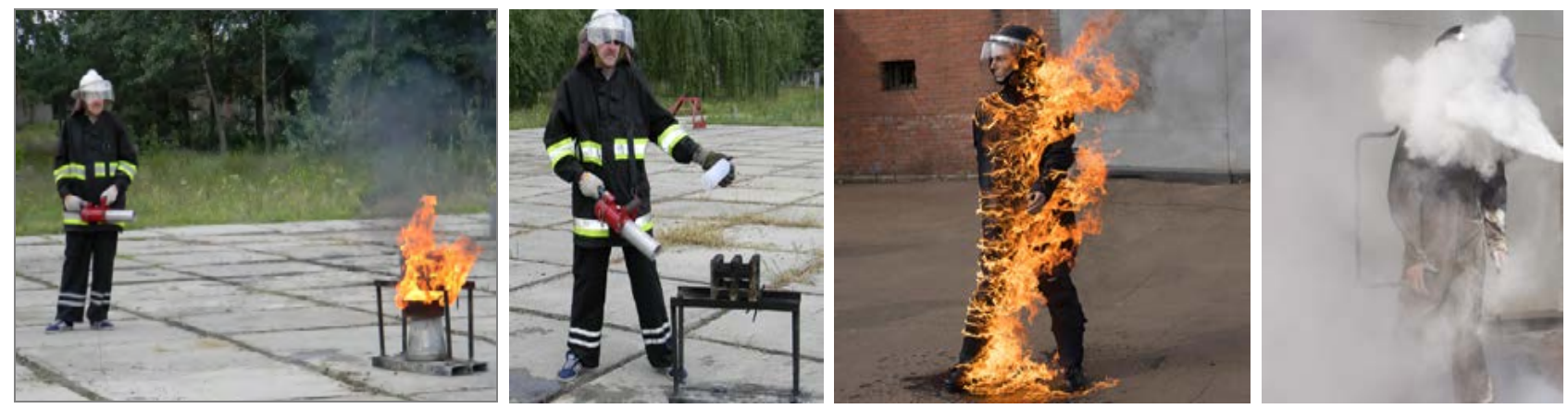

Fig. 3. Professional professional fire extinguisher, certified in Ukraine in 2012 
quality of extinguishing Forest fires, at the initial stage of burning several separate sources that are difficult and expensive to extinguish from an airplane and a helicopter. It is also effective for extinguishing fires in a garden, cottage, rural houses, sheds, combines, tractors, automobiles: the instantaneous elimination of arsons and the extinguishing of burning people, such as a policeman in burning clothes, a combine operator, an operator in an oiled overalls. In Fig. 3. A hand sprayer is shown - a fire extinguisher spraying 1 liter of water with a shot and extinguishing the model center A- 0.1 for the first time in one second and from a distance of $5 \mathrm{~m}$, this center after 6 minutes. Free burning to quench is much more difficult than burning clothes on a person; $b$ - extinguishing burning clothes on the upper part of a person with one shot of $0.35 \mathrm{~kg}$ powder.

The strongest side of impulse quenching and protection is the complexity of the mechanisms of simultaneous exposure, which allows to reduce the specific costs of sprayed compounds and natural materials to the utmost and, as a result, allows them to extinguish or protect large-scale autonomously for the first time.
The impulse technique easily implements repeated or repeated exposure with flexibly controlled parameters, which, according to the decision of the operator or the robot, provides the reinforcement or weakening of the next impulse vortex exposure compared to the previous one. This technique will allow you to quickly prevent the development of fires and disasters in urban environments in enterprises with high fire risk. In this case, the determining factor for the success of operations is the scale and diversity of the impact. A unique feature is the creation of moving vortices and non-transparent gas-dispersed static media in combination with flexibly controlled local deposition (enlightenment) according to a given program, which makes it technically simple and easy to create escape routes.

The use of universal systems of pulsed vortex spraying to protect civilians and troops from fires, explosions, high-precision weapons, toxic radioactive fallout, ensuring evacuation from fire zones, puts this equipment at a special place on the expediency of financing its development and improving models of equipment and methods for their application.

\section{References}

1. Zakhmatov V.D., Puzyna O.V. Protection of police officers in the conditions of mass riots. Protection and security. 2014. № 2 (69). P. 10-11.

2. Viktor Bulat, Michel Chernushev. Accelerate the gas waveform. Dispersed medium and accelerate for gas-dispersed whirly or gasdroplet squall. WAVE MODELING 2018 Prague, Czech Republic, September 17-21, 20181 ECCOMAS Regional Conference.

3. Nick Sherback. Multi-barrels, air conditioning systems, oil and gas wells, platform terminals, oil-gas wells, platform terminals, oil-gas wells, platform terminals. Book of the 3rd Quingdao International Technology Transfer Conference \& US Innovative Enterprise Technology Negotiation Meeting. 182 pages, 37-38 p.

4. Sterback N. Pulse Method \& Equipment for Forest, High-Efferctive Fire-Fighting, Prevent 7-category Accident, Stop Terrorist attacks, Multi-protection at Nuclear Power Stations- NPS. Proceeding of 2016 China-Ukraine Forum on Science and Technology, July 5th-8th. 2016. P. 93-95.

5. Silnikov M.V., Chernyshov M.V. Flags of the Space Rocket for Spacecraft Starting. European Journal of Natural History. 2016. №. 4. P. 72-79.

6. Yanson L.M. Effects of liquid superheat on droplet distortion in supersonic flow. Thesis of Worcester polytechn. Inst. $2005.65 \mathrm{p}$.

7. Luxford G., Hammond D.W., Ivey P. The role of droplet distortion and breakup in large droplet aircraft icing. AIAA, Paper. 2004. №. 2004-411.

8. Park S.W., Kim S., Lee C.S. Breacup and atomization of mono-dispersed diesel droplets in cross-flow air stream. Int.J. Multiphase flow. 2006. V. 32. №. 7. P. 807-822.

9. Duan R.Q., Koshizuka S., Oka Y. Two-dimensional simulation of the weber number. Nuclear eng. and design. 2003. V. 225. № 1. P. 38-48.

10. Nomura K. Et al. Numerical analysis of droplet behavior using the particle method. J. of nuclear xcience and technology. 2001. V. 38. №. 12. P. 1057-1064.

11. Chernyshov M.V., Danilov N.A. Research and optimization of shock-wave systems and structures in problems of aerogasdynamics and explosion protection. XI All-Russian Congress on problems of theoretical and applied mechanics: a collection of reports. Kazan : Kazan publishing house. University, 2015. P. 4067-4070.

12. Bochkareva E.M. et al. Decrease in vapor pressure during condensation on cold drops of liquid. Engineering Physics Journal. 2016. T. 89. № 3. S. 542-547.

13. Zakhmatov V.D., Silnikov M.V., Chernyshov M.V. Overview of Impulse Fire-Extinguishing System Applications. Journal of Industrial Pollution Control. 2016. Vol. 32. №. 2. P. 490-499.

14. Zakhmatov V. Torud, pommid ja labidad - plahvatuslik tuletorjetehnoloogia. Inseneeria, Tallinn, Estonia. 2014. № 2. P. 14. 